\title{
Commentary: Automatic distal anastomotic connector-Carrying away a small stone toward moving the entire robotic coronary artery bypass grafting mountain
}

Oz M. Shapira, MD, Ahmad Mahajna, MD, and Gal Aviel, MD

\author{
From the Department of Cardiothoracic Surgery, Hadassah Hebrew University Medical Center, Jerusalem, Israel \\ Disclosures: Authors have nothing to disclose with regard to commercial support. \\ Received for publication Sept 5, 2019; revisions received Sept 5, 2019; accepted for publication Sept 10, 2019; \\ available ahead of print Oct 24, 2019. \\ Address for reprints: Oz M. Shapira, MD, Hadassah Hebrew University Medical Center, POB 12000, Ein-Kerem, \\ Jerusalem 91120, Israel (E-mail: ozshapira@ hadassah.org.il). \\ J Thorac Cardiovasc Surg 2020;159:e61-2 \\ $0022-5223 / \$ 36.00$ \\ Copyright (c) 2019 by The American Association for Thoracic Surgery \\ https://doi.org/10.1016/j.jtcvs.2019.09.039
}

The man who moves a mountain begins by carrying away small stones.

-Usually attributed to Confucius

(552 вСЕ-479 вСЕ)

The first-in-human robotically assisted totally endoscopic coronary artery bypass (TECAB) was performed in 1999. ${ }^{1}$ The concept was embraced by only a handful of surgeons because of its enormous technical challenge. A decade later, a state-of-the-art review headed by one of the early adaptors predicted that "given the ongoing development in hardware, software, and surgical techniques, robotically-assisted $\mathrm{CABG}$ is here to stay, and broader application is most likely." 2 Indeed, because of the vision and strong commitment of a few pioneers, the TECAB procedure advanced from a robotic internal thoracic artery harvesting only to a single-vessel coronary artery bypass grafting $[\mathrm{CABG}]$ and to multivessel $\mathrm{CABG} .^{2-5}$ TECAB has been performed as a stand-alone procedure or as a component of a hybrid coronary revascularization in conjunction with percutaneous coronary intervention. ${ }^{4,5}$

Despite the great progress, TECAB is infrequently used by coronary surgeons. Since its inception, TECAB has been routinely performed by just a few very dedicated teams worldwide. In a recent report from the Society of Thoracic Surgeons Adult Cardiac Surgery Database, the use of robots has increased from $0.59 \%$ to $0.97 \%$ of CABG procedures performed in the United states between 2006 and $2012 .{ }^{6}$ The reluctance of the cardiac surgeon community to adopt this approach stems from a number of issues. First is limited applicability. A stand-alone TECAB on an arrested or a beating heart is currently performed mostly for a 1- or 2vessel coronary disease. ${ }^{3-5}$ These indications account for a small minority of patients referred for $\mathrm{CABG}^{7}$ Second is a slow learning curve. The TECAB procedure is technically

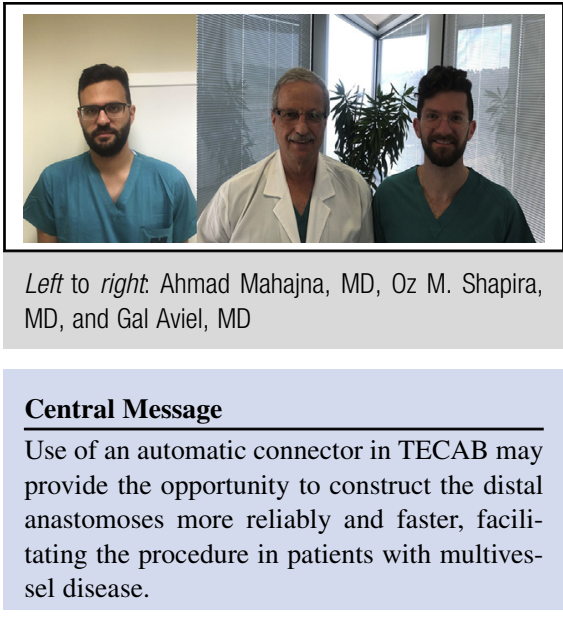

See Article page e57.

complex. Successful implementation requires a dedicated team effort and adequate case volume. ${ }^{2-5}$ Third is lack of strong evidence that TECAB is associated with superior outcomes relative to conventional CABG. The current TECAB outcomes data are based on retrospective singleinstitutional reports on small, low-risk patient cohorts. In experienced centers, TECAB was associated with as predicted (but not superior) low mortality and major complications and improved short length of stay, early return to work, and quality of life. ${ }^{2-5}$ High rates of reoperation for bleeding and conversion to an "open" case, however, remain major concerns. $^{2-5}$ Fourth is the significant amount of resources required to implement and maintain a robotic program, which might be unjustified in light of the limited applicability and convincing outcomes data.

So, should the TECAB idea be abandoned? Absolutely not! In this issue of the Journal, Hashimoto and colleagues ${ }^{8}$ describe the technical details of using an automatic connector to construct the distal left internal thoracic artery-to-left anterior descending coronary artery anastomosis. ${ }^{8}$ Although TECAB with this connector is still complex and perhaps not applicable to the entire spectrum of coronary artery atherosclerotic pathology, this technical progress may provide the opportunity to construct the distal anastomoses more precisely, reliably, and faster than with the robotically hand-sewn technique. The anastomotic 
connector described by Hashimoto and colleagues ${ }^{8}$ has been previously evaluated for vein-to-coronary anastomosis, with excellent short-term patency rates. ${ }^{9}$ In a more recent report from Balkhy and colleagues, ${ }^{4}$ the use of the distal anastomotic connector expanded TECAB to patients with multivessel disease, with excellent clinical outcomes and midterm graft patency.

TECAB may not be ready yet for "prime time." The pioneering group of Hashimoto and colleagues, ${ }^{8}$ however, have (once more) moved away a small but critical stone, in the effort to move the entire TECAB mountain of challenges.

\section{References}

1. Loulmet D, Carpentier A, d'Attellis N, Berrebi A, Cardon C, Ponzio O, et al. Endoscopic coronary artery bypass grafting with the aid of robotic assisted instruments. J Thorac Cardiovasc Surg. 1999;118:4-10.

2. Bonnati J, Schachner T, Bonaros N, Lehr EJ, Zimrin D, Griffith B. Robotically assisted totally endoscopic coronary bypass surgery. Circulation. 2011; 124:236-44.
3. De Cannière D, Wimmer-Greinecker G, Cichon R, Gulielmos V, Van Praet F, Seshadri-Kreaden U, et al. Feasibility, safety, and efficacy of totally robotic coronary artery bypass grafting: multicenter European experience. J Thorac Cardiovasc Surg. 2007;134:710-6.

4. Balkhy H, Nisivaco S, Kitahara H, McCrorey M, Patel B. Robotic multivessel endoscopic coronary bypass: impact of a beating-heart approach with connectors. Ann Thorac Surg. 2019;108:67-73.

5. Gaudino M, Bakaeen F, Davierwala P, Di Franco A, Fremes SE, Patel N, et al. New strategies for surgical myocardial revascularization. Circulation. 2018;138: 2160-8.

6. Whellan DJ, McCarey MM, Taylor BS, Rosengart TK, Wallace AS, Shroyer AL, et al. Trends in robotic-assisted coronary artery bypass grafts: a study of the Society of Thoracic Surgeons Adult Cardiac Surgery Database, 2006 to 2012. Ann Thorac Surg. 2016;102:140-6.

7. Sousa-Uva M, Head SJ, Milojevic M, Collet JP, Landoni G, Castella M, et al. 2017 EACTS guidelines on perioperative medication in adult cardiac surgery. Eur J Cardiothorac Surg. 2018;53:5-33.

8. Hashimoto M, Wehman B, Balkhy HH. Robotic totally endoscopic coronary artery bypass: tips and tricks for using an anastomotic device. J Thorac Cardiovasc Surg. 2020;159:e57-60.

9. Matschke KE, Gummert JF, Demertzis S, Kappert U, Anssar MB, Siclari F, et al. The Cardica C-Port system: clinical and angiographic evaluation of a new device for automated, compliant distal anastomoses in coronary artery bypass grafting surgery -a multicenter prospective clinical trial. J Thorac Cardiovasc Surg. 2005; 130:1645-52. 